\title{
Experimental behaviour of Self Compacting Concrete Filled Steel Rectangular Fluted Columns for Concentric Load
}

\author{
Eramma. $\mathrm{H}^{1}$, B.R. Niranjan ${ }^{2}$ \\ ${ }^{1,2}$ (Department of Civil Engineering, University Visvesvaraya College of Engineering, J.B. Campus, Bangalore \\ University Bangalore- 560056 India)
}

\begin{abstract}
A well planned experimental work on thirteen regular concrete filled steel fluted columns (CFSFC). The parameters chosen for the study are Geometry of the specimen - Rectangular flutes. Different LD ratios, Longitudinal reinforcement. Three series of specimens having different L/D ratios, $2500 \mathrm{~mm}$ long have been tested with $M_{20}$ grade of concrete. Study has been made with respect to the Self Compacting Concrete as per Nan Su method and tested for conformity as per IS Specifications is poured into the fluted steel tube. These columns were cured for 28 days by frequently pouring water over top of the column. Pilot specimens cured in a similar manner were tested to know the basic properties. It has been found from the observation that columns had good confinement and SCC the failure was at supports for all columns by opening up of steel sheet showing local buckling. It was also observed that as the LD ratio increased the opening up of steel sheet moved towards the supports. None of the columns showed any buckling characteristics for enhanced loading or for higher $L / D$ ratios of 25. Results obtained from the experiments have been compared with earlier developed empirical equations and have been found that generally, the theoretical values are conservative compared to the experimental values by about 50 to $60 \%$.
\end{abstract}

Keywords - CFSRFC, CFST, Composite Column, Rectangular Fluted column, SCC

\section{INTRODUCTION}

CFST (Concrete Filled Steel Tubes) Columns came into existence during early 1960. Substantial research has been made to understand the behaviour since then (1-21).The advantage of using these CFST Columns have been found by Japanese first and employed in the construction of multi-storied buildings effectively. Now, the analysis and Design of these CFST Columns have found place even in Codes and Specifications. It has been envisaged to study strength, stiffness and buckling characteristics by providing flutes to steel sheet of columns which enhances aesthesis of columns. Also, fluted columns enhances the strength and also stiffness as the surface area of steel sheet and moment of inertia of the column increases. The advantage of steel members having high tensile strength and ductility and concrete members having better compressive strength have been better made use as a composite member. Additional longitudinal reinforcement in the columns makes the columns still stronger. Hence, it has been envisaged to check whether such a columns would act as a slender column.

Research has been in progress around the world on experimental and analytical studies on Concrete Filled Steel Tubular Columns for more than four decades. Substantial contribution has been made since then in understanding the behaviour of CFST columns and to arrive at a design procedure. Quite few countries have incorporated the design procedure in their respective codes also.

Most of the researchers ${ }^{(1-21)}$ have considered the contribution of geometric properties like shape, L/D ratio, t/D ratio, boundary conditions, strength of materials and the loading conditions. It has been found that generally the failure occurs by either local buckling or yield failure. It has been found that Euro code gives a better design method which yields values nearer to experimental values.

\subsection{SCC:}

The introduction of self compacting concrete(SCC) technology has significantly changed the way the concrete operation is executed. It enables improvements in the concrete construction techniques for increased and efficient results. Elimination of discontinuous mechanical vibration makes concrete structures more consistent having reliable properties. General enhancement of the working environment is paid off by improvement in health and safety of workers, which also adds to the increase of productivity. SCC is new and improved way of executing the concreting operations, while maintaining homogeneity without the need for external vibration. 


\section{Requirements for SCC}

SCC exhibits following properties in its plastic state.

> Filling Ability: It is the ability of SCC to flow into and fill completely all spaces in the formwork and encapsulate reinforcement while maintaining homogeneity.

> Passing Ability: It is the ability of concrete mix to pass through obstacles like narrow sections in form work, closely spaced reinforcement bars without getting blocked by interlocking of aggregate particles.

> Resistance to segregation: Segregation resistance of self compacting concrete is its capability to retain homogeneity in the distribution of ingredient in fresh state during both static and moving condition i.e., during mixing, transportation and placing. It is dependent on viscosity of mix in fresh state.

\subsection{Materials}

Materials were used in this study like Cement, Fine aggregate, Coarse aggregate, Flyash, GGBFS, Super Plasticizer (SP) and Viscosity Modifying Agent (VMA) for mixing SCC concrete, steel sheet, Fe 415 reinforcement and their characteristics obtained by testing of materials.

\subsection{Testing Methods for SCC}

\section{Cement}

Birla super (53 grade) cement

\section{Tests on cement}

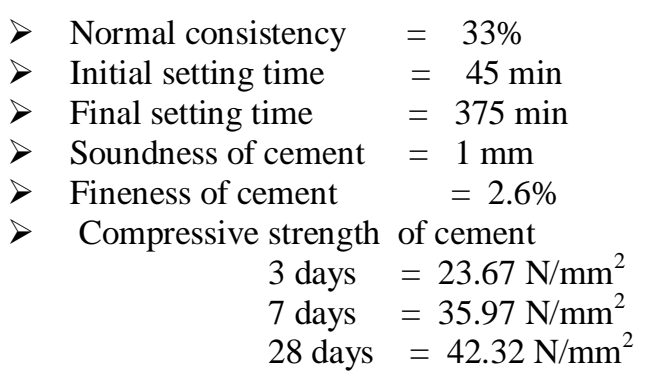

\subsection{Design mix for SCC by Nan Su method}

Details of selecting a suitable SCC mix for evaluating its performance in terms of strength and durability are described. For selecting a suitable mix using local aggregates, eight trial mixes were considered by varying the mix parameters, such as quantity of filler and super plasticizer and fine aggregate/coarse aggregate ratio, while keeping the water/powder ratio constant. Proportioning of the trial mixes was carried out using the absolute volume method. Each mix was tested for self compatibility and compressive strength. Finally, a suitable mix was selected based on the self-compatibility and strength test results.

\section{Data's are obtained from experimental program}

$>$ Packing factor $(\mathrm{PF})=1.07$

$>$ Sp gravity of Cement $\left(\mathrm{G}_{\mathrm{c}}\right)=3.1$

$>\mathrm{Sp}$ gravity of $\mathrm{FA}\left(\mathrm{G}_{\mathrm{s}}\right) \quad=2.66$

$>$ Sp gravity of $\mathrm{CA}\left(\mathrm{G}_{\mathrm{g}}\right) \quad=2.7$

$>$ Sp gravity of Flyash $\left(\mathrm{G}_{\mathrm{f}}\right)=2.1$

$>$ Sp gravity of GGBS $\left(\mathrm{G}_{\mathrm{b}}\right)=2.97$

$>$ Sp gravity of water $\left(\mathrm{G}_{\mathrm{w}}\right)=1.0$

Bulk density of FA $\left(\mathrm{W}_{\mathrm{sl}}\right)=1589 \mathrm{Kg} / \mathrm{m}^{3}$

$>$ Bulk density of $\mathrm{CA}\left(\mathrm{W}_{\mathrm{gl}}\right) \quad=1569 \mathrm{Kg} / \mathrm{m}^{3}$

$>$ Max size of aggregate $=10 \mathrm{~mm}$

$>$ The ratio of flyash / GGBS $=7 / 3$

$>$ The volume ratio of fine / coarse aggregate $=58 / 42$

> Super Plasticizer (SP) = Glenium B233(BASF chemicals company)

$>$ Viscosity Modifying Agent (VMA) = Structuro 480 (FOSROC chemicals company)

$>$ Air content $(\mathrm{Va})=1.5 \%$

$>$ Designed compressive strength (psi) $\mathrm{f}^{1} \mathrm{c}=20 \mathrm{MPa}$ 
Mix Proporations:

Cement : Fine Aggregate : Coarse Aggregate : Flyash : GGBS : Water : SP : VMA

$145: 986: 705: 204.4: 87.6: 176.92: 6.118: 0.437$

$1: 6.8: 4.86: 1.40: 0.60: 1.22: 0.042: 0.003$

\subsection{Tests conducted on SCC}

1. Slump flow test

2. $\quad \mathrm{V}$ - funnel flow test

3. L-box test

4. U-box test

\subsubsection{Slump flow test}

Slump test is one of the most popular method of measuring workability throughout the world. The slump flow is used to assess the horizontal free flow of SCC in the absences of obstructions. The slump cone, filled with concrete, if lifted off and concrete will flow - the horizontal diameter of the flowed material is measured. The average diameter of the concrete circle is measure for filling ability of the concrete. The $\mathrm{T}_{50}$ time is a secondary indication of flow, it measures the time taken in secs from the instant the cone is lifted to the instant when horizontal flow diameter reaches $500 \mathrm{~mm}$ as shown in Fig 1.1 According to Nagataki and Fujiwara $^{23}$, a slump flow ranging from 500 to $700 \mathrm{~mm}$ is considered to be self-compacted. At more than 700 $\mathrm{mm}$ the concrete might segregate and at less than $500 \mathrm{~mm}$ the concrete may have insufficient flow to pass through highly congested reinforcement.

\section{Concrete spread diameter}

$\mathrm{d} 1=630 \mathrm{~mm}$ and $\mathrm{d} 2=630 \mathrm{~mm}$

$\operatorname{Avg}=\frac{(d 1+d 2)}{2}=\frac{(630+630)}{2}=630 \mathrm{~mm}$

Perimeter $(\mathrm{P})=2040 \mathrm{~mm}, \mathrm{P}=\pi \mathrm{x} \mathrm{d}$

$\mathrm{d}=\frac{p}{\pi}=\frac{2040}{\pi}=649.50 \mathrm{~mm} \quad(600 \mathrm{~mm}-700 \mathrm{~mm})$ hence safe

\subsubsection{V-funnel flow test}

The flowability of the fresh concrete can be tested with the V-funnel test, where by the flow time is measured. The funnel is filled with about 12 liters of concrete and the time taken for it to flow through the narrow end of the apparatus is measured. Further, another parameter $\mathrm{T}_{5} \mathrm{~min}$, is also measured with $\mathrm{V}$ - funnel. This is to indicate the tendency for segregation. For this, the funnel is refilled with concrete and left for 5 min to settle. If the concrete has exhibited segregation the flow time will increase significantly, compared to the measurement as shown in Fig 1.2

Time required to concrete flow through $\mathrm{v}-$ funnel $=12$ secs $(8-12$ secs $)$ Hence safe.

\subsubsection{L - box test}

Passing ability of SCC is determined using the L-box test. The vertical section of the L-box is filled with concrete, and then the gate lifted to let the concrete flow in to the horizontal section. The height of the concrete at the end of the horizontal section is expressed as a proportion of that remaining in the vertical section ( $\mathrm{H} 2$ / H1 ) as shown in Fig 1.3(a) and 1.3(b)

$\mathrm{H} 1=100 \mathrm{~mm}$ and $\mathrm{H} 2=90 \mathrm{~mm}$

Ratio $\frac{H 2}{H 1}=\frac{90}{100}=0.9(0.8-1.0)$ Hence safe.

\subsubsection{U-Box Test}

The test was developed by the Technology Research Centre of the Taisei Corporation in Japan. Sometimes the apparatus is called a "box - shaped "test. The test is used to measure the filling ability of self compacting concrete. The apparatus consists of a vessel that is divided by a middle wall into two compartments as shown in Fig 1.4

Height of the concrete in first compartment $\mathrm{H} 1=270 \mathrm{~mm}$

Height of the concrete in second compartment $\mathrm{H} 2=260 \mathrm{~mm}$

Passing ability of concrete

$\mathrm{H} 1-\mathrm{H} 2=270-260=10 \mathrm{~mm}$ (Max difference is allowed $30 \mathrm{~mm}$ ) Hence safe. 


\subsubsection{Chemical Admixtures}

Superplasticizers are an essential component of SCC to provide necessary workability. The new generation superplasticizers termed poly-carboxylated ethers (PCE) is particularly useful for SCC. Other types may be incorporated as necessary, such as Viscosity Modifying Agents (VMA) for stability, air entraining agents (AEA) to improve freeze - thaw resistance, and retarders for control of setting.

\subsubsection{Fly ash}

Fly ash in appropriate quantity may be added to improve the quality and durability of SCC.

\subsubsection{Ground Granulated Blast Furnace Slag ( GGBFS)} properties

GGBFS which is both cementitious and pozzolanic material may be added to improve rheological

\subsubsection{Casting and curing of specimens}

From each trial mix, a total number of 3 cubes concrete specimens were prepared. $150 \mathrm{~mm}$ in length and $150 \mathrm{~mm}$ height, were cast for determining the compressive strength after 7, 14 and 28 days of water curing as shown in Fig 1.5

\section{Compressive strength of SCC

$$
\begin{aligned}
7 \text { days } & =13.47 \mathrm{~N} / \mathrm{mm}^{2} \\
14 \text { days } & =15.70 \mathrm{~N} / \mathrm{mm}^{2} \\
28 \text { days } & =27.10 \mathrm{~N} / \mathrm{mm}^{2}
\end{aligned}
$$

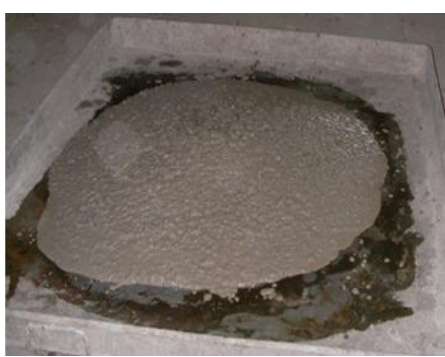

Fig.1.1 Slump flow

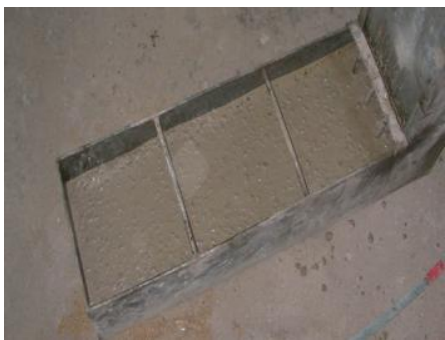

Fig $1.3(b) L-b o x$

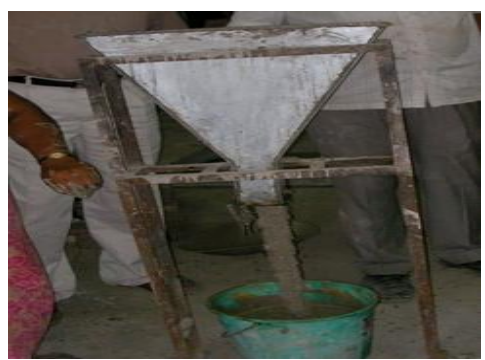

Fig 1.2 V-funnel flow

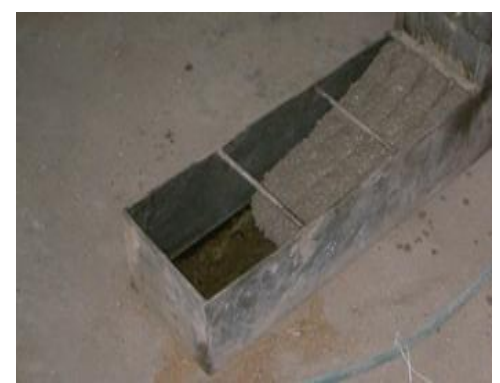

Fig $1.3(a) L-b o x$

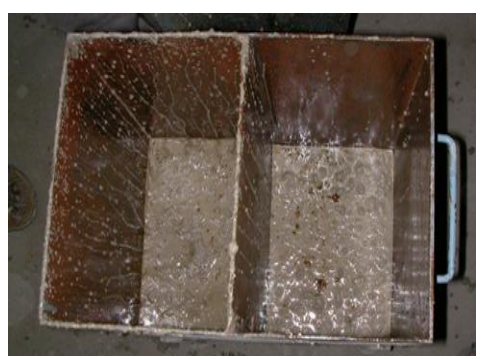

Fig 1.4 U-Box

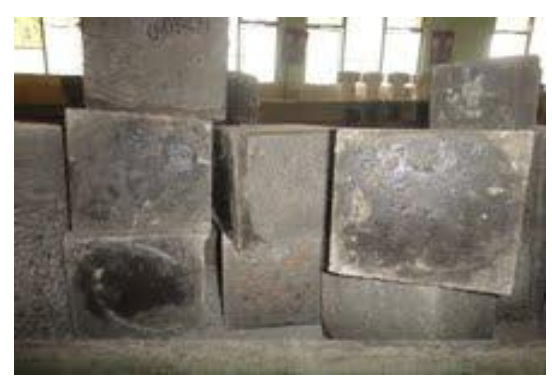

Fig 1.5 Piloted Specimens

II.

\subsection{Preparation of Specimen}

EXPERIMENTAL INVESTIGATION

Mild steel sheet having thickness $0.8 \mathrm{~mm}$ has been pressed in a mill to obtain five rectangular fluting of $40 \mathrm{~mm}$ width $10 \mathrm{~mm}$ at apex uniformly along the length. These sheets were given a tubular shape and tacked along the edges at an interval of $250 \mathrm{~mm}$ along the length of the column. The number and the size of the flutes remained same irrespective of the diameter of the column i.e., for different L/D ratios. The development length of the width of each of these columns with different L/D ratios as compared to a circular column of the same diameter is 24,29 and $34 \%$ for L/D ratios of 15, 20 and 25 respectively. Reinforcement cage is then placed inside these fluted tubes taking care to maintain the necessary cover. The five types of columns have been shown in Fig 2.1.Though regular ties have not been used, however four ties have been provided at equal distances to keep the reinforcement in position. A Self Compacting Concrete of design mix $\mathrm{M}_{20}$ designed as per Nan Su method ${ }^{(22)}$ and tested for conformity as per IS specifications is poured into the fluted steel tube. These 
columns were cured for 28 days by frequently pouring water over top of the column. Pilot specimens cured in a similar manner were tested to know the basic properties and are entered in Table 1.

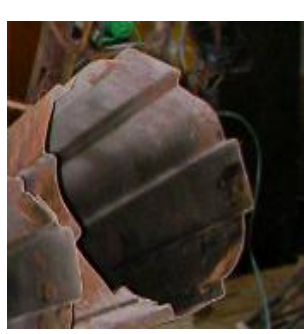

No Reinforcement

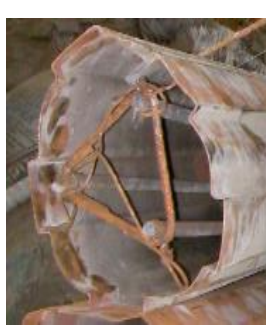

$3 \# 8$

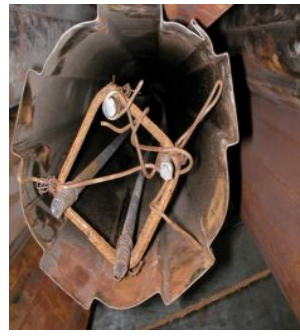

$4 \# 8$

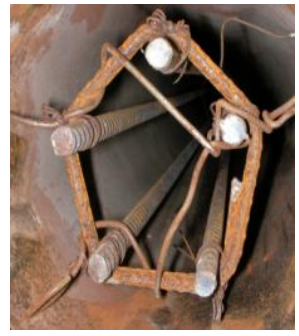

$5 \# 8$

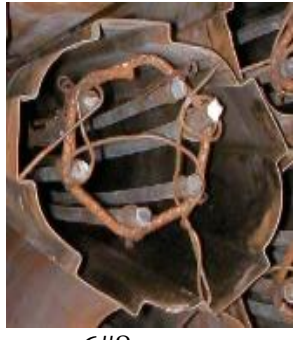

$6 \# 8$

Fig 2.1. Rectangular fluted steel tube with and without reinforcement

\subsection{Experimental Setup}

The tests were conducted using a $2000 \mathrm{kN}$ capacity hydraulic jack placing the specimen in the testing machine as shown in Fig.2.2. The bearing surfaces of the testing machine and the bearing plates were wiped clean and any loose sand or other material removed from the surface of the specimen. Which were to be in contact with the bearing plates. The specimen was placed between the bearing plates in such a manner that the upper bearing plate was directly in line with the lower plate and the bearing plates extend at least $25 \mathrm{~mm}$ from each end of the specimen. The columns were at placed restraining rotation at both ends. Care was taken to ensure that truly axial load was transformed to each of the columns. This was achieved by using plumb bob and Theodolite.

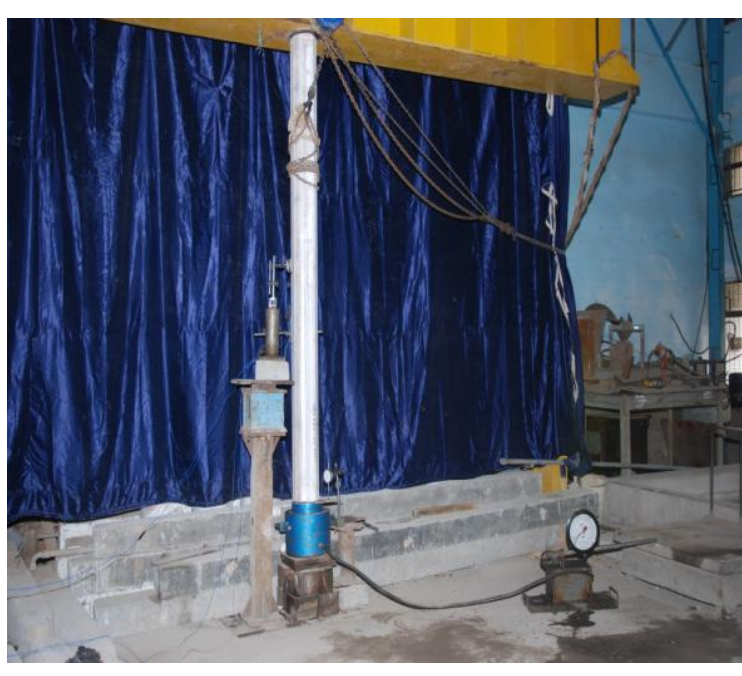

Fig 2.2. Experimental Setup

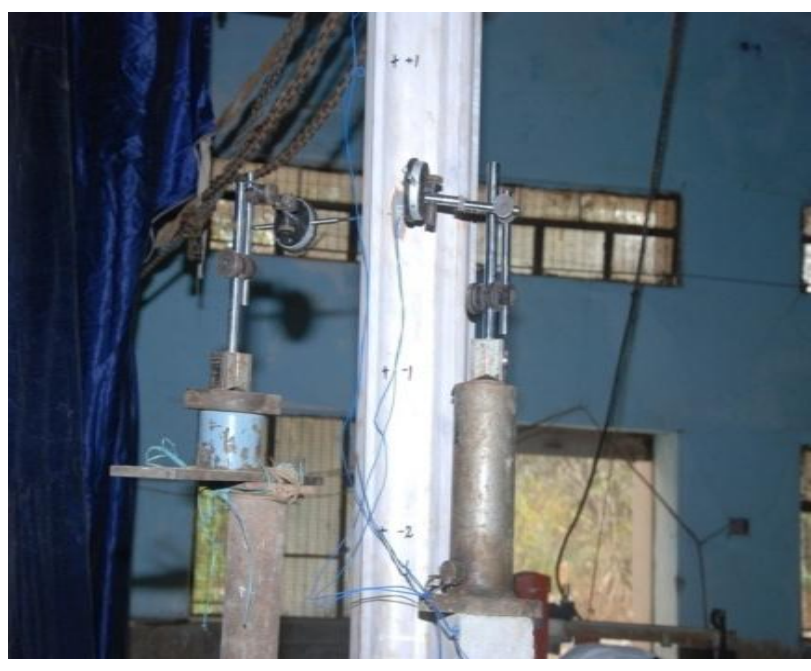

Fig 2.3 Connection of Dial Test Indicators laterally

\subsection{Instrumentation}

Foil strain gauge ( $8 \mathrm{~mm} \times 8 \mathrm{~mm}) 350+0.5 \Omega$ has been used to measure the strains at the centre of the steel tube and centre of the reinforcement (core) of the specimens. Three numbers $50 \mathrm{~mm}$ dial test indicator with a least count of $0.01 \mathrm{~mm}$ one for axial and the other two for lateral were used to measure axial and lateral deformations upon loading as shown in Fig 2.3. Apart from these instruments plumb bob and linear scales have been used.

\section{RESULTS AND DISCUSSION}

Behaviour of the columns has been studied with respect to deformation characteristics in the axial direction and in the transverse direction. Strains have been measured on the steel sheet in two perpendicular directions.

Generally the columns have shown linear behaviour up to about one third of the total load that is about $200 \mathrm{kN}$ axial compressive load. It was envisaged to study the buckling characteristic because of the less width to length of column. None of the columns have shown buckling, near the mid portion of the column. The confinement of the column is so large and even the columns without the longitudinal reinforcement have not 
shown any buckling. All the columns have failed near supports of column showing local buckling .Columns with L/D ratio of 25 also have not buckled. Behaviour of each column and its characteristics have been explained in subsequent articles. Among various number of reinforcements, the ultimate load has been found to be maximum for L/D ratio of 15, 20 and 25 to be in 4 number of reinforcements as shown in Fig.3.

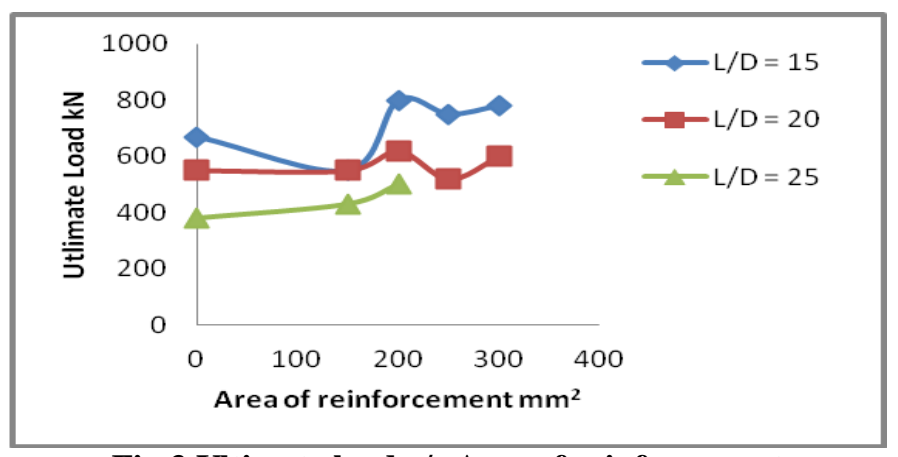

Fig 3 Ultimate load v/s Area of reinforcement

IV. EMPIRICAL EQUATIONS

These results of tests of CFSFC have been compared with the results of various existing theoretical equations given here under.

\subsection{Euler's equations}

$$
\mathrm{P}_{\mathrm{cr}}=\frac{\pi^{2} E I}{l^{2}}=\mathrm{f}_{\mathrm{c}} \mathrm{A}
$$

\subsection{Rankine-Gorden's formula}

$$
\mathrm{P}=\frac{f_{C} \times A}{\left(1+\alpha\left(\frac{I}{k}\right)^{2}\right)}
$$

\subsection{Secant formula}

$$
P=\frac{f \times A}{\left[1+e\left(\frac{Y c}{k^{2}}\right)\right] \times\left\{1+a\left(\frac{1^{2}}{k^{2}}\right)\right\}}
$$

\section{4 Tangent Modulus equation}

$$
\left(\frac{p}{A}\right)_{\mathrm{cr}}=\frac{\pi^{2} E_{\mathrm{t}}}{\left(\frac{1}{k}\right)^{2}}=\mathrm{f}_{\mathrm{c}} \times \text { A }
$$

\subsection{Rankine-Merchant's formula}

$$
\left.\mathrm{f}_{\mathrm{ac}}=\left\{0.66 \frac{\left[\mathrm{f}_{\mathrm{cc}} \mathrm{x}_{\mathrm{y}}\right\}}{\left[\mathrm{f}_{\mathrm{cc}}{ }^{\mathrm{n}}+\mathrm{f}_{\mathrm{y}}{ }^{\mathrm{n}}\right]}\right]^{\left(\frac{1}{2}\right)}\right\}
$$

\subsection{Infilled columns}

$$
P a=1.1 A_{c} f_{c c}\left[1-\left(\frac{0.000025 L^{2}}{r_{c}^{2}}\right)\right]+A_{s} f_{s c}+\mathrm{A}_{\mathrm{st}} \mathrm{f}_{\mathrm{st}}
$$

\subsection{IS: 456-2000}

$$
\mathrm{P}_{\mathrm{u}}=0.4 \mathrm{f}_{\mathrm{ck}} \mathrm{A}_{\mathrm{c}}+0.67 \mathrm{f}_{\mathrm{y}} \mathrm{A}_{\mathrm{sc}}
$$

\section{Composite section}

$$
P_{u}=0.4 f_{c k} A_{c}+0.67 f_{y} A_{s c}+0.67 f_{s s} A_{s c}
$$

Reduction factor $\mathrm{C}_{\mathrm{r}}$ has not been considered as none of the columns have shown any sort of buckling

\subsection{Nominal Design}

$$
\mathrm{p}=\mathrm{p}_{1}+\mathrm{p}_{2}+\mathrm{p}_{3}
$$

Where $\mathrm{p}_{1}=\mathrm{Lxtx} \mathrm{f}_{\mathrm{y}}$ ( Load taken by steel sheet)

$\mathrm{p}_{2}=\mathrm{A}_{\mathrm{c}} \times \mathrm{f}_{\mathrm{ck}}=\left[\left(\pi(\mathrm{d})^{2} / 4\right)+5(1 \times \mathrm{h})\right] \times \mathrm{f}_{\mathrm{ck}} \quad($ Load taken by concrete $)$

$\mathrm{p}_{3}=\mathrm{A}_{\mathrm{st}} \times \mathrm{f}_{\mathrm{y}}=\left[\left(\pi(\mathrm{d})^{2} / 4\right) \times \mathrm{n}\right] \times \mathrm{f}_{\mathrm{y}}($ Load taken by reinforcement $)$

These equations have been modified to consider equivalent area, moment of inertia and young's modulus of that of CFSFC members. The values obtained from these equations have been compared with the experimental values and are tabulated in table 2. It can be observed that the values obtained by Secant and 
Experimental behaviour of Self Compacting Concrete Filled Steel Rectangular Fluted Columns for Rankine's Merchant equation are about $40 \%$ conservative as compared to that of no reinforcement column for the column with $\mathrm{L} / \mathrm{D}$ ratio of 15,20 and 25 .

The following Fig 4.[ Fig 4(a) to Fig 4 (d)] shows the failure of columns buckling does not exist even L/D 25
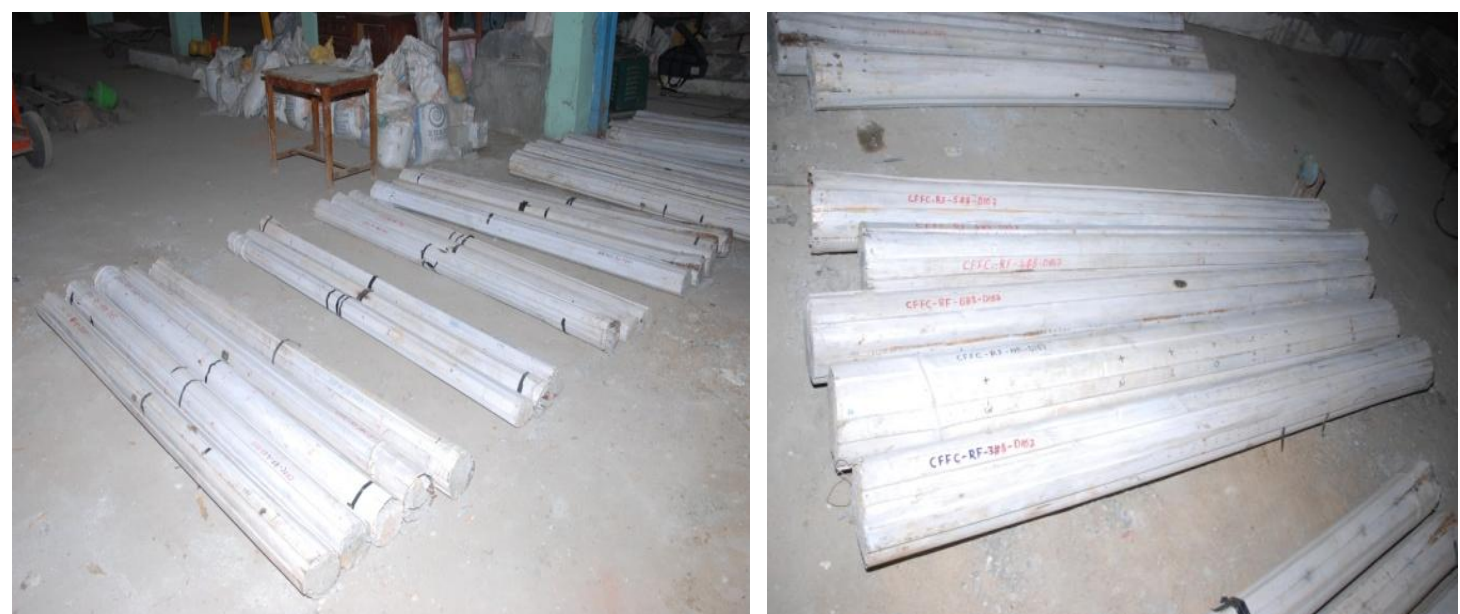

4(a). Failure of all columns ( buckling does not exist)
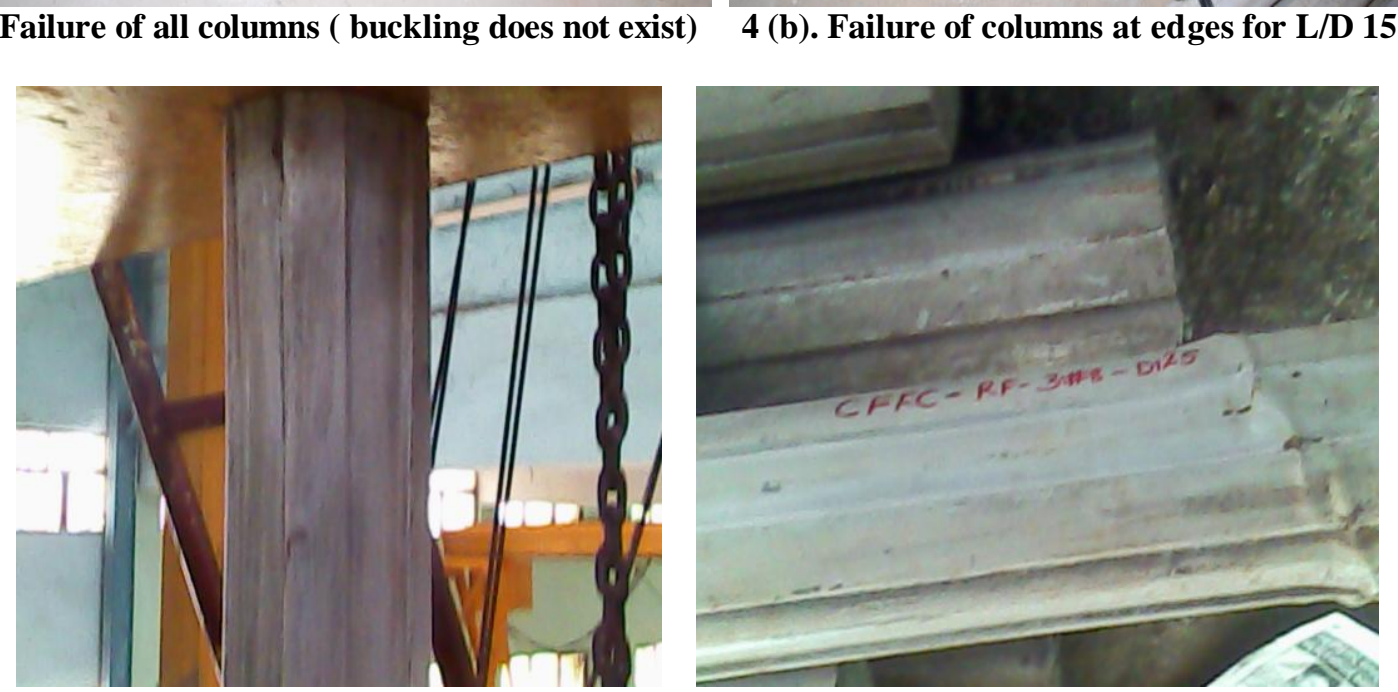

4(c) Failure of column L/D 25 at top with 3/\#8 4(d) Failure of column CFSFC L/D 20 at bottom with 3/\#8

Fig 4. Failure of columns 


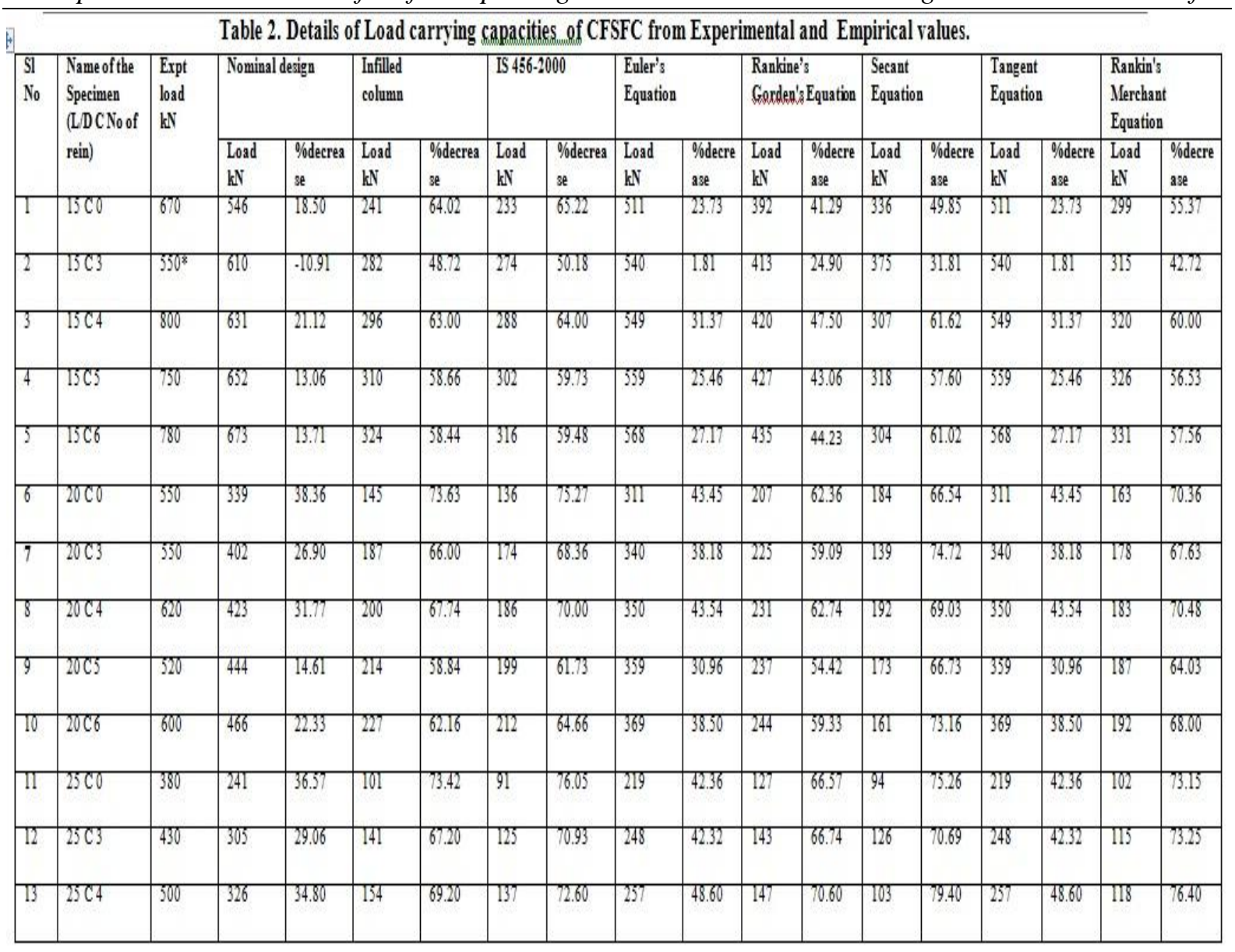

${ }^{8}$ Without arc weld column. First experiment test the sheet is opened up, immediately put arc weld for remaining columns,

\section{CONCLUSION}

$>\quad \mathrm{SCC}$ has been one of the most significant achievement in concrete construction process.

$>\quad$ For Columns without reinforcement, the ultimate load for L/D ratio of 20 and 25 reduced by $18 \%$ and $43 \%$ as compared to the Column with L/D ratio of 15.

$>\quad$ The reinforcement improves the axial strength of the column by about $19 \%, 13 \%$ and $32 \%$ for 4 number of reinforcements with $\mathrm{L} / \mathrm{D}$ ratio of 15,20 and 25 as compared to the column with no reinforcement.

$>\quad$ The strength of Column reduces by $23 \%$ and $38 \%$ when L/D ratio reduces from 15 to 20 and 15 to 25 .

$>\quad$ It can be observed that the values obtained by Secant and Rankine's Merchant equation are about $40 \%$ conservative as compared to that of no reinforcement column for the column with L/D ratio of 15, 20 and 25 .

$>\quad$ the ultimate load has been found to be maximum for L/D ratio of 15, 20 and 25 to be in 4 number of reinforcements

$>\quad$ All the columns have failed near the supports of the column.

$>\quad$ As the reinforcement in the column increased the distance of failure point moves towards centre of the column and as L/D reduces the failure point moves towards the support.

$>\quad$ As number of reinforcement increases the distance of failure due to buckling has also increased by $43 \%$, $22 \%, 65 \%$ \& $43 \%$ respectively. For 3,4,5 \& 6 number of reinforcements for $\mathrm{L} / \mathrm{D}=15$. Similar results have also been found for other L/D ratios.

$>\quad$ No buckling has been observed for any of the columns even with higher L/D ratio of 25

\section{Acknowledgements}

The authors wish to thank the authorities of Bangalore University for giving an opportunity to conduct the experiments in the Structural Engineering Laboratory of Faculty of Engineering-Civil. 


\section{REFERENCES}

\section{Journal Papers:}

[1] Artiomas Kuranovas, Audronis Kazimieras Kvedaras 2007, "Behavior of hollow concrete-filled steel tubular composite elements", Journal of Civil Engineering and Management 2007, Vol XIII, No 2, 131-141

[2] Bridge, RQ \& O'Shea, MD,1997, "Local buckling of thin-walled circular steel sections with or without internal restraint" Journal of Constructional Steel Research, vol. 41, No.2/3, pp. 137-157.PII:S0143-974X(97)00002-3

[3] Bridge, RQ \& O'Shea, MD, 1998, "Behavior of thin-walled steel box sections with or without internal restraint", Journal of Constructional Steel Research, vol. 47, pp. 73-91.

[4] Bridge, RQ \& O’Shea, MD, 2000, "Design of circular thin-walled concrete filled steel tubes "Journal of Structural Engineering, ASCE, Proc. 126, 1295-1303.

[5] Brian Uy, 2001, "Local and post-local buckling of fabricated steel and composite cross sections", Journal of Structural Engineering, ASCE, vol. 127, no. 6, pp.666-677.

[6] Bradford, MA, Loh, HY \& Uy, B, 2002, "Slenderness limits for circular steel tubes", Journal of Constructional Steel Research, vol. 58, pp. 243-252.

[7] Brian Uy et al, 2003, "Strength of Concrete Filled Steel Box Columns Incorporating Interaction Buckling", Journal of Structural Engineering,ASCE, vol 129 pp. 626-639.

[8] Dung M. Lue, Jui-Ling Liu, Tsong Yen 2007, "Experimental study on rectangular CFT columns with high-strength concrete", Journal of Constructional Steel Research, 63 (2007) 37-44.

[9] Giakoumelis. G \& Lam. D, 2004, "Axial capacity of circular concrete-filled tube columns", Journal of Constructional Steel Research, vol. 60, pp. 1049-1068

[10] Ferhun C. Caner; and Zdenek P. Bazant, F., 2002, "Lateral Confinement Needed to Suppress Softening of Concrete in Compression Journal of Engineering Mechanics, December 2002 pp 1304-1313.

[11] Fam, A, Qie, FS \& Rizkalla, S, 2004, "Concrete-filled steel tubes subjected to axial compression and lateral cyclic loads", Journal of Structural Engineering, ASCE, vol. 130, no. 4, pp. 631-640.

[12] Huang C. S. et al 2002, “Axial Load Behavior of Stiffened Concrete-Filled Steel Columns", Journal of Structural Engineering September 1222-1230.

[13] Hu, HT, Huang, CS, Wu, MH \& Wu, YM, 2003, "Nonlinear Analysis of Axially Loaded Concrete-Filled Tube Columns with Confinement Effect", Journal of Structural Engineering, ASCE, vol. 129, no. 10 pp. 1322-1329.

[14] Johansson, M \& Gylitoft, K,2002, 'Mechanical behavior of circular steel composite stub columns', Journal of Structural Engineering, ASCE, vol.128, no.8,pp.1073-81.

[15] Kefeng Tan, John M. Nichols and Xincheng Pu 2003, "Mechanical Properties of High Strength Concrete Filled Steel Tubular Columns: Part 1 - Concentrically Loaded”, ACI Journal April 2003.

[16] Liang QQ, Uy B \& Liew JYR, 2006, "Nonlinear analysis of concrete-filled thin-walled steel box columns with local buckling effects", Journal of Constructional Steel Research, vol. 62, pp. 581-591.

[17] Min - Lang Lin and Keh- chyuan Tsai, " Mechanical behavior of double-skinned composite steel tubular columns “, National Center for Research on Earthquake Engineering, Taipei, Taiwan.

[18] Shosuke Morino, Keigo Tsuda, "Design and construction of concrete-filled steel tube column system in Japan", Earthquake Engineering and Engineering Seismology, Vol. 4, No. 1 pp 51-73.

[19] X.X Zha \& Sumei Zhang 2003, "Comparison with current codes in the world for Concrete Filled Steel Tubular structures" Harbin Institute of Technology, China.

[20] Zeghichea .J, K. Chaoui, 2005, “An experimental behavior of concrete-filled steel tubular columns”, Journal of Constructional Steel Research 61 (2005) 53-66.

[21] Zhi-wu Yu, Fa-xing Ding, 2007, "Experimental behavior of circular concrete-filled steel tube Nan Su, Kung-Chung Hsu, His-Wen Chai "A simple mix design method for self stub columns", Journal of Constructional Steel Research 63 (2007) pp. 165-174

[22] Nan Su, Kung-Chung Hsu, His-Wen Chai " A simple mix design method for self - compacting concrete" Cement and Concrete Research 31 (2001) $1799-1807$.

[23] Nagataki, S and Fujiwara, H., "self compacting property of highly flowable concrete", V.M. Malhotra (ED), American Concrete Institute, SP 154 (1995), pp 301-314, June.

[24] Khayat, K.H., and Manai, K., Les betons autonivlants: properties, characterisation et applications, Colloque sur les betons autonivlants, University de Sherbrooke, Canada, November 1996, 28 pp.

[25] Skarendahl, A and Petterson,O. State of the art report of RILEM technical committee 174 - SCC, Self-Compacting Concrete, Paris, RILEM.M Ozaki, Y. Adachi, Y. Iwahori, and N. Ishii, Application of fuzzy theory to writer recognition of Chinese characters, International Journal of Modelling and Simulation, 18(2), 1998, 112-116. (8)Note that the journal title, volume number and issue number are set in italics.

\section{Books:}

[26] Dayaratnam.P, Limit state design of reinforced concrete structures, 2004

[27] Sinha S.N, Reinforced Concrete Design, First Revised Edition, Tata McGraw Hill publishing company limited.

[28] CHU-KIA WANG and CHARLESS G. SALMON, Reinforced Concrete Design, Sixth Edition, International Text book company.

[29] Krishna Raju .N, Advanced reinforced concrete design, CBS Publications.

[30] Dr.Prakash Rao D.S, Strength of materials, A practical approach Volume1, University press (India) Limited Publications

[31] Ashok. K. Jain, Reinforced Concrete Limit State Design, Third Edition 1989. Published by Nem Chand \& Bros, Civil lines Roorkee INDIA.

[32] Shetty, M.S., "Concrete Technology" Theory and Practice., First Multicolour Illustrative Revised Edition 2006.

[33] Krishna Raju . N ; "Design of Concrete Mixes", Third Edition, 1988, CBS Publishers \& Distributors.

[34] Neville, A.M ; "Properties of Concrete", Fourth Edition 2006, Published by Dorling Kindersley (India) Pvt, Ltd.

[35] Gambhir, M.L; "Concrete Technology "Third Edition 2006, Published by Tata McGraw-Hill Publishing Company Limited

[36] Neville, A.M \& J.J Brooks ; “Concrete Technology” First Edition 2006, , Published by Dorling Kindersley (India) Pvt, Ltd.

[37] Santhakumar, A.R; "Concrete Technology", Oxford Hihger Education 2007, Published in India by Oxford University Press. 